\section{Bulk tank somatic cell count and associated microbial quality of milk from selected dairy cattle herds in Oyo State, Nigeria}

\author{
Olufemi Olatoye, ${ }^{1,2}$ Adesola Amosun, ${ }^{3}$ \\ Uzo Ogbu, ${ }^{1}$ Yemi Okunlade $^{1}$ \\ ${ }^{1}$ Department of Veterinary Public \\ Health and Preventive Medicine, \\ University of Ibadan, Nigeria; ${ }^{2}$ Paul \\ Allen G. School for Global Animal \\ Health, Washington State University, \\ Pullman, WA, USA; ${ }^{3}$ Department of \\ Veterinary Microbiology and \\ Parasitology, University of Ibadan, \\ Nigeria
}

\section{Abstract}

Improvement of traditional and nomadic milk production through dairy development program in Nigeria requires routine quality and safety monitoring of milk both at herd level and milk collection centers. A total of 411 bulk raw milk samples aseptically obtained from Ibarapa, Oyo and Oke-Ogun industrial milk collection centers were subjected to California Mastitis Test (CMT), Bulk Somatic Cell Count (BSCC) and bacteriological analysis for assessment of quality and safety of milk from the herds. One hundred and seven $(26.0 \%)$ of the samples were CMT positive, while $74.0 \%$ were negative to CMT. The overall mean BSCC, TAC and TCC were $1.27 \times 10^{3} \pm$ cells $/ \mathrm{mL}, 1.12 \times 10^{3} \pm 34 \mathrm{cfu} / \mathrm{mL}$, $97.8 \pm 9.8 \mathrm{cfu} / \mathrm{mL}$ in the CMT negative milk samples while for the strong positive samples the mean BSCC, TAC and TCC were $4.33 \times 10^{6} \pm$ cells $/ \mathrm{mL}, 2.35 \times 10^{6} \pm 453$ $\mathrm{cfu} / \mathrm{mL}, 189.3 \pm 41.1 \mathrm{cfu} / \mathrm{mL}$ respectively; these were higher than the Pasteurized Milk Ordinance acceptable limits. Positive correlation was found between CMT scores and bacterial contamination and between CMT scores and SCC was recorded. About 26.0\% of the samples with positive CMT could be considered unsafe due to strong correlation with microbial contamination that could result in milk borne zoonoses and public health hazards. However, a greater proportion $(76.9 \%)$ of the milk with negative CMT scores could be safe for human consumption after post-harvest pasteurization. Consequently, there is need to improve handling, environmental and milking hygiene; as well as proper herd and udder health management to improve quality and safety of Nigeria dairy products.

\section{Introduction}

There is rising demand for milk and other dairy products in developing countries including Nigeria. Milk is an excellent source of high quality protein diet and also containing a lot of essential vitamins and minerals which can be easily digested and absorbed by all mammals especially the infants. Milk and milk products are major global diets providing about $5-10 \%$ of the total calories of the daily human diet in several countries and are the best natural sources of essential amino acids, calcium and phosphorus. These nutrients are essential role in body building, especially the bones and teeth development (Pandey and Voskuil, 2011). These nutritional attributes have made milk an acceptable and staple global diet of both infants, and adults.

The largest proportion of milk produced for human consumption is obtained from cattle. Dairy cows efficiently convert human-inedible food and by-products into nutrient-rich milk (van Hooijdonk and Hettinga, 2015). Annual milk production per cow in developed countries varies between $2539 \mathrm{~kg} / \mathrm{cow}$ in China to 9682 $\mathrm{kg} / \mathrm{cow}$ in the United States (IDF, 2012) against the average yield of about 295 to $2585 \mathrm{~kg}$ by the indigenous breeds of cattle that predominate the dairy sector in Nigeria (Shittu et al., 2012; Olorunnisomo, 2013).

Sokoto Gudali, White Fulani; Rahaji, Buzuwa, Red Sokoto and Jalli breeds are the indigenous breeds of dairy cattle commonly reared in several part of Nigeria. However, few farmers have tried to rear both the Holstein and Friesian breeds but with environmental, husbandry and disease challenges (Olorunnisomo, 2013). Sokoto Gudali constitutes about $70 \%$ of dairy cattle in Nigeria due to its relatively better adaptability to different agroecological zones of the country (Shittu et al., 2012). Majority of the cattle are reared by agropastoralists in extensive and semi-extensive system with low inputs from field grazing (Iyayi et al., 2003). The animals are kept in the open yards in clusters according to herdsmen ownership. The cows are milk early in the morning before taken out whole herds to the range for grazing and also, led to the streams or rivers from the late hours of the morning to return in early evening (Shittu, 2012).

Commercial dairy production in Nigeria has not been viable as a result of the traditional agropastoralism and nomadic systems of cattle husbandry coupled with the milk yield of the indigenous breeds of dairy cattle with little or no supplement inputs. Higher milk yields are usually obtained during the raining season than the dry season
Correspondence: Olufemi Isaac Olatoye, Department of Veterinary, Public Health and Preventive Medicine, University of Ibadan, Nigeria.

Tel.: +234.805.7852655.

E-mail: olatoyevet@yahoo.com

Key words: bulk somatic cells count, bacterial pathogens, dairy herds.

Acknowledgments: The authors acknowledge the assistance of cattle farmers and member of staff of the milk collection centers for sampling.

Contributions: OO, UO, sampling, sample collecting and analyzing; OO, YO, manuscript writing; $\mathrm{OO}, \mathrm{AA}$, manuscript reviewing and references search.

Conflict of interests: the authors declare no potential conflict of interests.

Funding: none.

Conference presentation: part of this paper was presented by $\mathrm{YO}$ at the 115th American Society for Microbiology ASM, 2015 General Meeting 2015 June 3-5, New Orleans LA USA.

Received for publication: 10 October 2017. Revision received: 31 January 2018. Accepted for publication: 28 February 2018.

This work is licensed under a Creative Commons Attribution-NonCommercial 4.0 International License (CC BY-NC 4.0).

(C) Copyright O. Olatoye et al., 2018 Licensee PAGEPress, Italy

Italian Journal of Food Safety 2018; 7:7130 doi:10.4081/ijfs.2018.7130

due to abundance of forage and water (Shittu et al., 2012). The traditional milking and milk processing by herdsmen and milkmaids are done in the village near the open yards, with the milk separated to portions to be consumed or sold raw and portions for processing into local dairy products such as Wara, Nono Manshanu and Kindirmo. The products are marketed by women and female children hawking along major roads and in rural markets (Ndambi et al., 2008).

The recent dairy farming improvement efforts in Nigeria through public-privatepartnership scheme comprising collection of milk from different cattle herds owned by nomadic and sedentary pastoralists. This Nigerian Dairy Development Program (NDDP) is geared towards improving the livelihoods of smallholder dairy farmers and improving cattle productivity by integraton traditional milk source into the formal dairy value chain in Nigeria. The 
herders are encouraged to supply bulk milk in tanks subsided by government to different private industrial milk collection centers for hygiene and safety value addition. NNDP established three milk collection centers in Oyo, Iseyin (Oke-Ogun), Maya (Ibarapa) town within the derived savanna of Oyo State where cattle are reared in the bush and villages around the milk collection centers. Pooled (bulk tank) raw milk are supplied to different collection centers transported in modern tanks via motor bikes or foot transport. The centers are equipped with milk holding facilities for screening and pasteurization after which it is subjected to industrial refrigeration and processing.

The husbandry and milking practice by the local dairy producers could result in poor milk quality, since milk is an excellent growth medium for both endogenous and environmental pathogenic and non-pathogenic bacteria (Olatunji et al., 2012). Microbial growth and multiplication in milk result from pre-harvest intramammary infections as well as milking and post milking environmental (Ruegg and Pantoja, 2013) contamination with deleterious effects on quality, wholesomeness and safety of milk and milk products.

Safe and high quality milk can only be obtained from mastitis free and healthy animals. Also, herd hygiene, management and milking processes influence the microbial quality of cow manure milk (Coorevits et al., 2008) while cows suffering from a disease could excrete the pathogenic bacteria in the udder with the milk, thereby predisposing consumers to food/milk borne disease. Milk borne outbreaks represent 2-6\% of bacterial food-borne outbreaks reported by surveillance systems from several countries (Brisabois and De Buyser, 2007).

Mastitis is an important disease of public health importance due to the consumption of raw or improperly pasteurized milk. Mastitis is an important disease of great economic importance in diary industry due to intramammary infection (IMI) which results into reduced secretory capacity of the mammary gland (Barbano et al., 2006). In general, mastitis is caused by bacteria pathogens such as Staphylococcus aureus, Streptococcus agalactiae, environmental streptococci and coliforms leading to direct milk contamination. Cows suffering from systemic disease could also secrete pathogenic bacteria such as Mycobacterium sp., Brucella sp. and Bacillus sp. Majority of the cattle herds are not under veterinary supervision without adequate disease and health programs especially without mastistis screening. Both clinical and subclinical mastistis in dairy cows in Nigeria have been reported by several authors (Amosun et al.,
2010; Junaidu et al., 2011; Shittu et al., 2012) Also, unregulated administration of antibiotics to cattle by the herdsmen could result in their residues that is also detrimental to milk quality and dairy technology (Ruegg and Tabone, 2000; Gonzalo et al., 2010).

Somatic cell count (SCC), total aerobic count (TAC) and total coliform count (TCC) used to assess fresh milk quality and safety. These parameters can be influenced by environment, milking practices and udder hygiene. Quality milk only originates from mastitis free and healthy animals. The hygienic standard of milk at farm-level, stage of lactation, feeding and housing systems of lactating cow influence the microbial quality of milk (Coorevits et al., 2008). Rinsing water for milking machine and milking equipment washing may also constitute a reason for the presence of a higher number of micro-organisms including pathogens in raw milk (Bramley, 1990).

Somatic cell count (SCC) means the number of body cells (primarily, the leukocytes, secretory cells and squamous cells) per millimeter of raw milk (NMC, 2013). SCC is also an indicator of cow/udder health and for screnning of mastitis. The standard SCC and BSCC of good quality fresh milk from a healthy cow is between $<100,000$ cells per $\mathrm{mL}$ and not greater than 500,000 cells per mL(PMO, 2009). Milk with high SCC has reduced shelf life, with the quality and yield of some milk products negatively affected (Barbano et al., 2006). SCC of milk is generally considered to be an important parameter for mastitis detection because inflammation of the mammary gland results in an influx of somatic cells, predominantly polymorph nuclear neutrophils (PMN), from the blood into the mammary gland (Burvenich et al., 1994). It has become the gold standard measure of milk quality (PMO, 2009). Clinical and subclinical mastitis are indicated in raw milk samples with a high somatic cell count and results in less nutritious milk or poor milk quality associated with low dairy management. California Mastitis Test (CMT) is a rapid, indirect qualitative measurement of milk somatic cell count for mastitis screening test routinely used for dairy udder health and milk quality (NMC, 2015). CMT is a rapid, and accurate cow-side test to help determine somatic cell counts (SCC) has been validated to be effective in detecting both clinical and subclinical mastitis (Kathiriya and Shah, 2009)

The test was developed to sample individual quarters for the presence of subclinical mastitis and can also be conducted on bucket and bulk tank milk samples to help determine somatic cell counts (SCC) of the entire herd.

Total aerobic count (TAC) is also used to estimates the total numbers of aerobic bacteria present in raw milk. This factor is used to determine how consistently clean milking practices are applied; udder hygiene, good mastitis prevention and control are practiced by dairy farmers. The limit according to the PMO (2009), for raw milk of good quality is set at $<10,000$ $\mathrm{cfu} / \mathrm{mL}$. While total coliform count (TCC) estimates the number of bacteria (enterobacteriacea) that originate from a contaminated environment or manure. Coliform count reflects hygiene and sanitation practices followed on farm. The high coliform count above $100 \mathrm{cfu} / \mathrm{mL}$ suggests poor milking practices, dirty equipments and facilities, contaminated water and/or cows with coliform mastitis. The somatic cell count (SCC) is the gold standard measure of milk quality as the herd SCC level is dependent on the number and duration of infections present plus rate of new infections (Reneau, 2011). The acceptable SCC value for high quality fresh milk is $\leq 500$ (PMO, 2009).

The unhygienic hand milking in the open filed with the milk pooled from unscreened cows collected and stored in local calabash guards commonly practiced by herdsmen in Nigeria portent food safety risks from such products. Private-PublicPartnership efforts of Nigeria government on dairy development aim at improvement of yield, safety and quality milk produced by indigenous cows. Improvement of traditional and nomadic milk production through dairy development programs in Nigeria will therefore require routine quality and safety monitoring of milk parmeters such as CMT, SCC, total aerobic plate count and coliform counts both at herd level and milk collection centers.

This study was aimed at determining the quality of raw milk produced from dairy herds in Oyo Sate supplied bulk to commercial milk collection centers in Oke-Ogun, Ibarapa and Oyo zones of the state in order to evaluate microbial and safety quality parameters of bulk tank milk supplied to the centers.

\section{Materials and Methods}

\section{Sample collection}

Milk Collection Center located OkeOgun, Ibarapa and Oyo zones of the state where the savannah agroecological vegetation support rearing of cattle. The fresh raw milk from each herd was pooled together in milking vessel with the portions to be sold to the milk collection centers poured into 
milk tank supplied by the centers. Each tank with milk from each herd is a member of the population from which samples were obtained. Sample size was calculated based on prevalence of mastitis reported by Shittu et al., (2012). A total of 411 samples (comprising: 113, 183 and 115 from Oke Ogun, Ibarapa and Oyo collection centers respectively) were obtained each into a $10 \mathrm{~mL}$ sterile sample bottle was aseptically and randomly collected. The samples were transported in ice-cooled box to the laboratory for analysis.

\section{California mastitis test}

The CMT-Test kit (BOVIVET $^{\mathrm{TM}}$ Kruuse, Langeskov, Denmark) comprising of a clean paddle and California Mastitis Test reagent was used according to the manufacturer's instruction. Briefly, $2 \mathrm{~mL}$ of milk sample and $3 \mathrm{~mL}$ of CMT test liquid were added aseptically to the CMT paddle and mixed gently moving in a circular motion and change in consistency for increase in the cell content of the milk was observed. The CMT was scored on a scale from 0 to 3 (CMT-Test, Kruuse, Langeskov, Denmark).

\section{Somatic cell count}

Somatic Cell Count was carried out by direct microscopic method (DMSCC) according to Nagy et al. (2013). Briefly, duplicate smears of $10 \mu \mathrm{L}$ milk were prepared on somatic cell slides (5638-01930, Bellco Glass Inc., Vineland, NJ), air-dried overnight, and fixed in Carnoy's fixative for $10 \mathrm{~min}$. Thereafter, the slides were left again in air for 20 to $24 \mathrm{~h}$ followed by staining with 2 drops of PMG (HT70116, Sigma-Aldrich, St. Louis, MO) for $2 \mathrm{~min}$. The PMG stain was removed with absorbent paper and the somatic cells were counted on 20 fields of one smear using a light microscope at $200 \times$ magnification. The final values (cells $/ \mathrm{mL}$ ) were calculated using the following equation: $\mathrm{SCC} / \mathrm{mL}=$ $(\Sigma 20$ fields $) \times 526.4$.

\section{Bacteriological analysis}

\section{Pre-enrichment of the milk samples}

The protocol according to EN ISO 8261 (E) 2001 was employed. This involved preenrichment in peptone water and 7-fold serial dilution of $1 \mathrm{~mL}$ of milk sample in 9 $\mathrm{mL}$ of buffered peptone water in sterile test tubes.

Total plate count and total coliform count

The protocol according EN ISO 4833 2003 was employed. Plate count agar was prepared according to manufacturer's recommendation. Then $0.1 \mathrm{~mL}$ of $10^{-5}$ and $10^{-7}$ sample dilutions were inoculated onto plates using the surface plate method. Replicate plates were labeled, cultured and incubated at $37^{\circ} \mathrm{C}$ for $18-24 \mathrm{hrs}$. TPC was obtained by counting the visible discrete colonies using the colony counter and calculated as colony forming unit per $\mathrm{mL}$ (cfu/mL) of milk. Also, for total coliform count, the EN ISO 48332003 was employed on MacConkey agar by surface plate method. Plates were labeled, cultured and incubated at $37^{\circ} \mathrm{C}$ for $24 \mathrm{hrs}$. Visible discrete coliform colonies were counted using the colony counter and calculated as colony forming unit per $\mathrm{mL}(\mathrm{cfu} / \mathrm{mL})$ of milk.

\section{Statistical analysis}

The mean SCC in samples from different locations results were compared using ANOVA, while correlations between the bacterial load and SCC were also determined.

\section{Results}

Out of the 411 bulk milk samples screened, negative CMT score was obtained in $304(74.0 \%)$ samples presumably of good quality, while 107 (26.3\%) samples scored weak to strong positive CMT values. The screening results of the samples from differ-

Table 1. Distribution of california mastitis test (CMT) scores of screened bulk-tank milk from Oyo State dairy herds.

\begin{tabular}{|c|c|c|c|c|}
\hline Location & $\begin{array}{c}\text { Negative to trace } \\
(\%)\end{array}$ & $\begin{array}{l}\text { CMT Class } 1 \\
\text { (weak + ve; \%) }\end{array}$ & $\begin{array}{c}\text { CMT Class } 2 \\
\text { (distinctive + ve; \%) }\end{array}$ & $\begin{array}{c}\text { CMT Class } 3 \\
\text { (strong + ve; \%) }\end{array}$ \\
\hline Oke Ogun & $87(78.0)$ & $9(7.0)$ & 13 (11.5) & $4(3.5)$ \\
\hline Ibarapa & $119(65.0)$ & 40 (21.9) & $15(8.2)$ & $9(4.9)$ \\
\hline Oyo & 98 (85.2) & $12(10.4)$ & $3(2.6)$ & $2(1.7)$ \\
\hline Total & $304(74.0)$ & $61(14.8)$ & $31(7.5)$ & $15(3.7)$ \\
\hline
\end{tabular}

Table 2. Mean somatic cell count in bulk-tank milk from dairy herds in Oyo State.

\begin{tabular}{|c|c|c|c|c|}
\hline Location & CMT Class & $\begin{array}{c}\text { Mean SCC } \\
(\text { cells } / \mathrm{mL} \pm \mathrm{SD})\end{array}$ & $\begin{array}{l}\text { Mean TBC } \\
\text { (cfu/mL) }\end{array}$ & $\begin{array}{c}\text { Mean TCC } \\
\text { (cfu/mL) }\end{array}$ \\
\hline Oke Ogun & $\begin{array}{l}\text { Negative to trace } \\
\text { CMT Class } 1 \\
\text { CMT Class } 2 \\
\text { CMT Class } 3\end{array}$ & $\begin{array}{c}1.5 \times 10^{3} \pm 234 \\
8.6 \times 10^{4} \pm 423 \\
3.1 \times 10^{5} \pm 452 \\
2.4 \times 10^{6} \pm 1468\end{array}$ & $\begin{array}{c}11 \times 10^{3} \pm 134 \\
18 \times 10^{3} \pm 324 \\
123 \times 10^{3} \pm 1434 \\
239 \times 10^{3} \pm 453\end{array}$ & $\begin{array}{c}83 \pm 34 \\
1023 \pm 212 \\
1624 \pm 323 \\
36307.8 \pm 16\end{array}$ \\
\hline Ibarapa & $\begin{array}{l}\text { Negative to trace } \\
\text { CMT Class } 1 \\
\text { CMT Class } 2 \\
\text { CMT Class } 3\end{array}$ & $\begin{array}{l}1.2 \times 10^{3} \pm 579 \\
6.2 \times 104 \pm 427 \\
8.3 \times 10^{5} \pm 724 \\
6.3 \times 10^{6} \pm 3624\end{array}$ & $\begin{array}{c}10 \times 10^{3} \pm 34 \\
22 \times 10^{3} \pm 324 \\
112 \times 10^{3} \pm 1403 \\
203 \times 10^{3} \pm 453\end{array}$ & $\begin{array}{c}102 \pm 34 \\
923 \pm 62 \\
1324 \pm 323 \\
24107.8 \pm 16 \\
\end{array}$ \\
\hline Oуо & $\begin{array}{l}\text { Negative to trace } \\
\text { CMT Class } 1 \\
\text { CMT Class } 2 \\
\text { CMT Class } 3\end{array}$ & $\begin{array}{l}1.1 \times 10^{3} \pm 215 \\
2.5 \times 10^{4} \pm 142 \\
5.3 \times 10^{5} \pm 807 \\
4.3 \times 10^{6} \pm 1207\end{array}$ & $\begin{array}{l}12 \times 10^{3} \pm 34 \\
25 \times 10^{3} \pm 324 \\
123 \times 10^{3} \pm 1434 \\
249 \times 10^{3} \pm 453\end{array}$ & $\begin{array}{c}10^{3} \pm 13 \\
10^{4} 6.4 \pm 62 \\
2124 \pm 323 \\
26107.8 \pm 816\end{array}$ \\
\hline Total & $\begin{array}{l}\text { Negative to trace } \\
\text { CMT Class } 1 \\
\text { CMT Class } 2 \\
\text { CMT Class } 3\end{array}$ & $\begin{array}{c}1.27 \times 10^{3} \pm 224 \\
5.77 \times 10^{4} \pm 1630 \\
5.57 \times 10^{5} \pm 735 \\
4.33 \times 10^{6} \pm 1325\end{array}$ & $\begin{array}{l}1.12 \times 10^{3} \pm 34 \\
2.25 \times 10^{3} \pm 321 \\
1.20 \times 10^{5} \pm 1434 \\
2.35 \times 10^{6} \pm 453\end{array}$ & $\begin{array}{r}98 \pm 34 \\
1223 \pm 275 \\
1424 \pm 313 \\
24307.8 \pm 176 \\
\end{array}$ \\
\hline
\end{tabular}


ent collection centers are shown in Table 1. Milk samples from Ibarapa presented the lowest negative CMT scores and highest positive CMT scores. However, there were no significance differences $(\mathrm{P}>0.05)$ in the CMT scores in the samples from the three collection centers.

\section{Somatic cell count in bulk raw milk}

The overall mean somatic cell count of $1.27 \times 10^{3} \pm 224$ and $4.33 \times 10^{6} \pm 1325$ cells $/ \mathrm{mL}$ were obtained in CMT negative and CMT positive milk samples from the study area with distribution across the milk collection centers for the different categories of milk quality based on CMT scores are presented in Table 1. The total mean SCC was significantly different from the values from the different locations $(\mathrm{P}<0.0001)$ and also showed a significant difference in samples from Ibarapa center against Oyo and Oke-Ogun centers ( $\mathrm{P}<0.001$ and $\mathrm{P}<0.01$ respectively) but no significant difference between Oke Ogun and Oyo.

\section{Total bacteria count and coliform count results}

The overall mean TBC and CC of the milk samples were $\log 8.03 \pm 0.20$ and $5.56 \pm 0.04$ respectively. Table 2 shows the contamination levels of the milk from the various centers in this study, there was no significant difference in bacterial loads across the 3 locations. The total bacteria count were significantly higher than $100,000 \mathrm{cfu} / \mathrm{mL}$ and results for coliform counts were significantly higher than acceptable limit of less than $100 \mathrm{cfu} / \mathrm{mL}$ (PMO, 2009).

\section{Correlation of somatic cell counts, total bacteria counts and coliform counts in bulk tank milk from Oyo State}

A positive correlation was obtained between the overall SCC scores and microbial load $($ corell $=0.977694 ; 0.526564$ respectively). Table 3 show the correlations at different milk collection centers with samples from Ibarapa and Oyo having positive correlations between SCC and TBC while samples from other centers were weak positive and negatively. The differences among the median log SCC of milk from different locations and bacteriological counts were not significant $(\mathrm{P}=0.24)$.

\section{Discussion}

Quality assessment of the raw milk produced from traditional dairy herds in Nigeria is critical to improvement and integration into the value chain of Nigeria dairy development. In this study the California mastitis test negative samples accounted for $74.0 \%$ and positives $26.0 \%$. At zonal level, $85.2 \%, 78.0 \%, 65.0 \%$ of the samples were CMT negative in Oyo, Oke Ogun and Ibarapa respectively. This result indicated that milk from about $23.1 \%$ had cows with certain degree of clinical, subclinical or chronic mastitis. The positive CMT results from the bulk milk imply that several cows with subclinical mastitis were milked across the herds in the state. Amosun et al., 2010 reported high prevalence of bovine mastitis among dairy herds in Oyo State, while Aminu et al., (2012) also reported overall herd-level prevalence of $85.33 \%$. Mean SCC values of $2.4 \times 10^{6}, 4.3 \times 10^{6}$ and $6.3 \times 10^{6}$ cells $/ \mathrm{mL}$ were obtained from milk in Oke-Ogun, Oyo and Ibarapa respectively, which are higher than the acceptable value of SCC in bulk tank milk of $\leq 500,000$ in USA, and $<400 \times 10^{3} \mathrm{cells} / \mathrm{mL}$ in EU, Australia, New Zealand and Canada (PMO, 2009; USDA, 2014). The herds with elevated SCC in study area could also be at different lactating periods of the cows and also resulted from indiscriminate antibiotics use by the farmers to treat or control intra-mammary bacterial infection (NMC, 2015). This can be due to mastitis at herd level. Seasonal changes and climate also play a role in producing milk with high SCC and maintaining mastitis in cows (Ruegg and Pantoja, 2013). Indiscriminate administration of antibiotics to cattle commonly practiced by the herdsmen with resultant residues in their milk can also be a cause of high SCC in milk from different herds. Which agree with the results of Ruegg and Tabone (2000) that presence of antibiotic

Table 3. Correlation between somatic cell count (SCC), total bacteria count (TBC) and coliform count (CC) in bulk-tank milk from dairy herds in Oyo State.

\begin{tabular}{lccc} 
Variables & SCC VS TBC & SCC VS CC & TBC VS CC \\
Oke Ogun & 0.098 & -0.202 & -0.079 \\
Ibarapa & 0.846 & 0.069 & 0.079 \\
\hline Oyo & 0.949 & -0.088 & -0.216 \\
Total & 0.731 & -0.023 & 0.079 \\
\hline
\end{tabular}

residues in milk positively correlated to increased BTSCC.

Also, the highest mean total bacteria count (TBC) of $2.35 \times 10^{6} \pm 453 \mathrm{cfu} / \mathrm{mL}$ obtained in the proportion of the milk samples with highest SCC and CMT positives and is significantly higher than the acceptable limit of $1 \times 10^{5} \mathrm{cfu} / \mathrm{mL}$ in raw milk. This could be as a result of pooling together of milk from cows at different lactation, mastitis, environmental contamination antibiotic resistance and post-partum immunosupression reduces the animal's ability to respond to exposure to pathogens (Ruegg and Pantoja, 2013). There was positive correlation between the values of milk quality factors (CMT, SCC and TBC) indicated that combinations of milking factors accounted for the results of the bulk milk quality in the study areas. The results of the coliform counts in the CMT positives were higher than acceptable limit of $<100 \mathrm{cfu} / \mathrm{mL}$ in raw milk (Reinemann et al., 1999). The highest mean coliform count obtained in milk from study area was $4.56 \log _{10} \mathrm{cfu} / \mathrm{mL}$ and is higher than that reported by Fekadu (1994) at 3.8, 4.0 and $3.8 \log _{10} \mathrm{cfu} / \mathrm{mL}$ of cows' milk from produced in Aneno, Gulgula and Dongora districts of southern region of Ethiopia respectively. This is indicative of the presence of fecal contaminants on the cow/udder, handlers, milking containers and in the milk. Multiple risk factors such as milking procedures at herds level, handling a transportation of bulk tank milk, personal hygiene and environmental contaminants could simultaneously affect the milk quality. Hillerton and Berry (2003) reported that the prevalence of contagious pathogens causing mastitis is decreasing and environmental causative agents are becoming dominant pathogens for mammary gland.

Traditional dairy practices of open field hand milking and unrefrigerated transportation of bulk tank milk in tropical condition could also account for the poor hygienic quality of milk screened in the study area. Amosun et al. (2010), isolated streptococci species of public health importance from dairy herds across the southern and northern states of Nigeria. Previous surveys indicates that dairy farmers and their families that consume raw (unpasteurized) milk produced on their farms and are among the demographic groups in the United States at greatest risk to food borne diseases (Oliver et al., 2005). This practice is also common among dairy cattle producers in dairy farms in Oyo State where they even go further to selling raw milk to consumers, hence wider public health consequences.

Unhygienic milking with fecal contamination could be associated with altered 
bacterial composition of the milk with coliform bacteria including $E$. coli and Salmonella that could be pathogenic. According to Martins et al. (2006), the conditions during storage and transport of raw milk in tanks cause the micro-biota to change from predominantly Gram-positive to predominantly Gram-negative organisms as they grow. Milk borne and milk-product borne outbreaks represent $2-6 \%$ of bacterial food-borne outbreaks reported by surveillance systems from several countries (De Buyser et al., 2001). Since the milk sampled in this study is from herds mostly reared on extensive management system, the hygiene and feeding levels could account for the milk quality obtained. Coorevits et al. (2008) reported that herd hygiene, management including feeding and housing strategies of dairy cows can greatly influence the microbial quality of milk.

\section{Conclusions}

This study obtained high incidence of CMT positive milk that correlated with high SCC as well as higher aerobic plate count and coliform count than acceptable limits. Dairy herd health and sound mastitis control program are require to address the husbandry, environmental, milking and other risk factors to reduce incidence of mastitis and improve milk quality. Also, there is need to improve milk handling, and transportation as well as farmers education on udder health management to improve quality and safety of Nigeria dairy products. There is need for organization and infrastructure that could integrate the traditional dairy producers with the Nigeria Dairy Development Program. The development of Nigerian dairy industry should be geared towards milk quality assurance encompassing the production, collection and marketing of high quality and safe milk. Herders and milkmaids should be trained on adequate pasteurization while consumption of raw milk should be discouraged.

\section{References}

Adesiyun AA, Webb LA, Romain HT, 1998. Prevalence and characteristics of Staphylococcus aureus strains isolated from bulk and composite milk and cattle handlers. J. Food Prot 61:629-32

Amosun EA, Ajuwape ATP, Adetosoye AI, 2010. Bovine Streptococcal mastitis in Southwest and Northern States of Nigeria. Afri J Biomed Res 13:33-7.

Bramley AJ, McKinnon CH, 1990. The Microbiology of Raw Milk. In:
Robinson RK, eds. Dairy Microbiology. Elsevier Applied Science, New York, NY, pp 171-175.

Brisabois A, De Buyser ML, 2007. Characterization of Staphylococcus aureus strains associated with food poisoning outbreaks in France. Int J Food Microbiol 115:369-75.

Burvenich CMJ, Paape AW, Hill AJ, Guidry RH, Miller R, Heyneman WDJ, Kremer A, Brand A, 1994. Role of the neutrophil leukocyte in the local and systemic reactions during experimentally induced E. coli mastitis in cows immediately after calving. Vet Q 16:45-9.

Coorevits A, De Jonghe V, Vandroemme J, Reekmans R, Heyrman J, Messens W, De Vos P, Heyndrickx M, 2008. Comparative analysis of the diversity of aerobic-spore-forming bacteria in raw milk from organic and conventional dairy farms. System Appl Microbiol $6: 25$.

Fekadu B, 1994. Present situation and future aspects of milk production, milk handling and processing of dairy products in Southern Ethiopia. Food production strategies and limitations: The case of Aneno, Bulbula and Dongora in Southern Ethiopia. Ph.D. Thesis, Department of Food Science. Agricultural University of Norway, Norway.

Fleming DW, Cochi SL, MacDonald KL, Brondum J, Hayes PS, Plikaytis BD, Holmes MB, Audurier A, Broome CV, Reingold AL, 1985. Pasteurized milk as a vehicle of infection in an outbreak of listeriosis. N Engl J Med 312:404-13.

Gonzalo C, Carriedo JA, García-Jimeno MC, Pérez-Bilbao de la Fuente LF, 2010. Factors influencing variation of bulk milk antibiotic residue occurrence, somatic cell count, and total bacterial count in dairy sheep flocks. J Dairy Sci 93:1587-95.

Hillerton JE, Berry EA, 2003. The management and treatment of environmental streptococcal mastitis. The Veterinary clinics of North America. Food Anim Pract 19:157-69.

Iyayi EA, Okoruwa VO, Babayemi OJ, Busari AA, Peters OF, 2003. Livestock production pattern of Agropastoralist in peri-urban centres of South- West Nigeria. Nig J Anim Prod 30:87-92.

Junaidu AU, Salihu MD, Tambuwal FM, Magaji AA, Jaafaru S, 2011. Prevalence of Mastitis in Lactating Cows in some selected Commercial Dairy Farms in Sokoto Metropolis. Adv Appl Sci Res 2011;2:290-4.

Kathiriya JB, Shah NM. A comparative study of different tests for diagnosis of sub-clinical mastitis in camels. Indian J Animal Res 43:6703-22.

Martins ML, Pinto CLO, Rocha RB, Araujo EF, Vanetti, MCD, 2006. Genetic diversity of Gram-negative proteolytic, psychrotrophic bacteria isolated from refrigerated raw milk. Int $\mathrm{J}$ Food Microbiol 111:144-8.

Nagy P, Faye B, Marko O, Thomas S, Wernery U, Juhasz J, 2013. Microbiological quality and somatic cell count in bulk milk of dromedary camels (Camelus dromedaries): descriptive statistics, correlations, and factors of variation. J. Dairy Sci 96:5625-40.

National Mastitis Council (NMC). 2015. Recommended Mastitis Control Program. Available from: www.nmconline.org/docs/NMCchecklistna.pdf Accessed November, 2016.

Ndambi OA, Garcia O, Balikowa D, Kiconco D, Hemme T, LataczLohmann U, 2008. Milk production systems in Central Uganda: a farm economic analysis. Trop Anim Health Prod 40:269-79.

Olatunji EA, Jubril AE, Okpu EO, Olafadehan OA, Ijah UJ, Njidda AA, 2012. Bacterial Assessment and Quality Analysis of Raw Milk Sold in Gwagwalada Area Council of the Federal Capital Territory (FCT) Abuja, Nigeria. Food Sci Qual Manage 7:222557.

Oliver SP, Jayarao BM, Almeida RA, 2005. Food borne pathogens in milk and dairy food environment: food safety and public health implications. Food Pathog Dis 2:114-29.

Olorunnisomo OA, 2013. Milk production in Sokoto Gudali cows fed legume or elephant grass ensiled with cassava peel. Livestock Research for Rural Development. 25: Retrieved January 30, 2018, from http://www.lrrd.org/lrrd25/6/olor25105. htm

Pandey GS, Voskuil GCS, ed. 2011. Manual on Milk safety, quality and hygiene. Golden Valley agricultural Research Trust, Zambia. pp 52.

PMO Grade "A" Pasteurized Milk Ordinance, 2009. U.S. Department of Health \& Human Service, Public Health Service, Food and Drug Administration. pp 405

Ruegg PL, Pantoja JCF, 2013. Understanding and using somatic cell counts to improve milk quality. Irish J Agric Food Res 52:101-17.

Ruegg PL, Tabone TJ, 2000. The relationship between antibiotic residue violations and somatic cell counts in 
Wisconsin dairy herds. J Dairy Sci 83:2805-9.

Shittu AA, Jamilu A, Jibril S, Mohammed AA, Fasina FO, 2012. Sub-clinical mastitis and associated risk factors on lactating cows in the Savannah Region of
Nigeria. BMC Vet Res 8:134-50.

USDA, 2014. Determining U.S. milk quality using bulk-tank somatic cell counts. Available from: https:/www.aphis.usda.gov/animal_he alth/nahms/.../BTSCC_2011infosheet.p df

Accessed on $15^{\text {th }}$ July, 2016.

van Hooijdonk T, Hettinga K, 2015. Dairy in a sustainable diet: a question of balance. Nutr Rev 73:48-54. 